\title{
ESTIMATION OF ANTICANCER EFFECT OF METHANOLIC EXTRACT OF ARTEMISIA HERBA ALBA ON HUMAN CANCER CELL LINES
}

\author{
Hadeer Y. Mohammed ${ }^{\star}$, Neima K. Al-Senosy, Naglaa M. Ebeed \\ and Fahmy Kh. \\ Genetic Dept., Fac. of Agric., Ain Shams Univ., P.O. Box 68, Hadayek Shubra 11241, \\ Cairo, Egypt \\ *Corresponding author: hadeer@agr.asu.edu.eg
}

Received 6 November, 2019

Accepted 24 November, 2019

\section{ABSTRACT}

Artemisia (Asteraceae family) has been reported to possess different bioactive phytochemicals including phenols, sesquiterpene lactones and flavonoids. The aim of this study was to estimate the anti-proliferative activity of the methanolic extract of Artemisia herba alba using in vitro assays on two of human cancer cell lines compared with the normal cell lines. The obtained results indicated that A.herba alba extract showed highly cytotoxic and anti-proliferative effects on tested human cancer cells as revealed by measuring viable mitochondrial oxidation of [3-(4,5-Dimethylthiazol-2-yl)2,5-diphenyltetrazolium bromide assay] (MTT assay). The observed (-IC50-) or the half-maximal inhibitory concentration of $A$. herba alba extract in the human hepatocellular carcinoma (HepG2) was $50.34 \mu \mathrm{g} / \mathrm{ml}$, while in the lung cancer cell line (A549) it was $29.23 \mu \mathrm{g} / \mathrm{ml}$. In contrast, the normal liver cells (THLE2) as well as lung normal cells showed very low sensitivity toward tested extract where the IC50 were $1250 \mu \mathrm{g} / \mathrm{ml}$ and $1915 \mu \mathrm{g} / \mathrm{ml}$, respectively. However, flow cytometric analysis for cell cycle using propidium iodide staining revealed increment of G2/M phase cell cycle arrest after treatment of HepG2 cells with $A$. herba alba extract. At the molecular level, the quantitative real time-PCR technique was used to investigate the alteration of gene expression after exposure of HepG2 cell line to $A$. herba alba extract by measuring levels of mRNA for p53, Bax, and Bcl-2 genes expression. The apoptotic mechanism was activated by the crude extract of $A$. herba alba extract included up-regulation of p53 and Bax and downregulation of $\mathrm{Bcl}-2$ expression levels. However, no cytotoxic effect was recorded after exposure of normal cell lines to the plant extract. These data indicated that $A$. herba alba extract possess antiproliferative effect by a cell cycle arrest at the G2/M phase and apoptosis mediated cytotoxicity in carcinoma cells. These results suggested that A.herba alba could contain one or more effective anti-cancer compound(s) and can be used as a natural source of anticancer agents.

Keywords: Medicinal plants, Anticancer effect, Artemisia herba alba, MTT assay, Apoptosis, QRT-PCR, Human cancer cell line

\section{INTRODUCTION}

According to the latest global cancer report for the international agency for research on cancer(IARC), the burden of cancer rised to $18.1 \mathrm{mil}-$ lion new cases and 9.6 million cancer deaths in 2018 (Bray et al 2018). It is still on the rise and that continue rising due to many factors such as environmental pollutions, population growth and ageing. The cancer expansion ratio related to the economic and social development (Gersten \& Wilmoth 2002).

Artemisia herba-alba (Family: Asteraceae) is an aromatic dwarf shrub rigid and grey native to the South Western Europe, Northern Africa, including Western Asia, Arabian Peninsula, and Libya which can grow in arid and semi-arid climates (Majdouli et al 2015). A recent review detailed the taxonomy, distribution, phytochemistry, morphology, and biological activities of $A$. herba-alba and its different extracts (Mohamed et al 2010). A. herbaalba with an Arabic name "Sheih", is a well-known 
medicinal plant that was used in the Middle East. It is traditional medicine plant for treating various diseases as an anti-diabetic (Mansi et al 2007 and Ashraf et al 2010), as antibacterial, analgesic, and hemostatic agents (Tilaoui et al 2011) and antioxidant (Jaleel et al 2016). It is also used for treating fever, menstrual and nervous problems (Abad et al 2012). In addition, A.herba-alba is used as antispasmodic, antimalarial and antibacterial agent (Aziz et al 2012). The essential oil of this herb is known to be responsible for its therapeutic use as disinfectant, anthelmintic and antispasmodic (Mohamed et al 2010). The Artemisia genus contains many bioactive agents such as artemisinin which exerts not only antimalarial effect but also profound cytotoxicity against tumor cells (Efferth, 2007).

Medicinal plants have a wide spectrum effect against variety of diseases or some disorder symptoms; therefore, they have an important role as a contributed agent in the industry of pharmacological drugs (Khalafalla et al 2010). Many studies have been conducted to investigate the phytochemicals of $A$. herba-alba, these studies revealed the presence of many important phytochemicals in different extracts either water or solvent such as Alcoholic, chloroform and other nonpolar solvents (Mohamed et al 2010). These phytochemicals include essential oils, sesquiterpene lactones, flavonoids and phenolic compounds (Tilaoui et al 2011 and Jaleel et al 2016).

Using of cancer cell lines model is in the origin of the development and test of anticancer drugs is presently used (Nakatsu et al 2005), it is proved to be good alternative to transplantable animal tumors in chemotherapeutics testing (Shoemaker, 2006). Cancer cell lines was used to study the proliferation deregulation, apoptosis and cancer progression (Vargo and Rosen, 2007). moreover, cancer cell lines model, was used to realize potential molecular markers (Van Staveren et al 2009) and for cancer therapeutics screening and characterization (Kao et al 2009). Using of cancer cell lines raised the information about the de-regulated genes and signaling pathways for this disease (Gazdar et al 2010). Cancer cell lines had been widely used for research aims and proved to be a useful tool in the genetic approach, and its characterization showed that they are, in fact, excellent models for the study of the genetic, epigenetic, cellular pathways and biological mechanisms involved in cancer (Louzada et al 2012), as well as, to development of new therapies (Pfragner et al 2009 and Louzada et al 2012). The research results in cancer cell lines are usually extrapolated to in vivo human tumors (Van Staveren et al 2009), and its importance as models for drug testing and translational study was recognized by many pharmaceutical and biomedical companies (Gazdar et al 2010).

The aim of this study was to assess the cytotoxic and anti-proliferative effects of methanolic extract of the medicinal plant A.herba-alba on cancer cell lines consulting MTT assay, flow cytometry and quantitative real time-PCR (qRT-PCR) assays.

\section{MATERIALS AND METHODS}

\section{Plant collection and Preparation}

Artemisia herba alba was collected from halazein valley - Matrouh governate, Egypt, and offered to our lab from Dr. Mohammed Abd ElMaaboud, Center of Desert Research, Agriculture Research Center. The whole plant was dried and ground. Plant extraction was prepared according to Gordanian et al (2014) with some modifications as the following; about $(60 \mathrm{~g})$ of dried grinded plant was soaked in $300 \mathrm{ml}$ of methyl alcohol overnight on shaker water bath at room temperature then the extracted material was filtrated and the filtrated material was let for air drying, which yielded $(6 \mathrm{~g})$. The extracted materials were stored at $-20^{\circ} \mathrm{C}$ up to use.

\section{Measurement of cytotoxic activity of plant extract using MTT assay}

MTT test was done on tumor cell lines of liver and lung as well as normal cell ones according to the Florento et al 2012. Assays were performed in three independent experiments using different concentration of plant extract. Sigmoidal and dose dependent curves were constructed to interpret the results of the experiment. The concentration of the compounds inhibiting $50 \%$ of cells (IC50) was calculated using this sigmoidal curve.

\subsection{Assessment of cell cycle using flow cy- tometry}

The culture of treated HepG2 cells was assessed using flow cytometry technique according to the method of Pozarowski and Darzynkiewicz (2004). The stained cells were read in Attune flow cytometer (Applied Bio-system, US) as shown in (Fig. 1). 


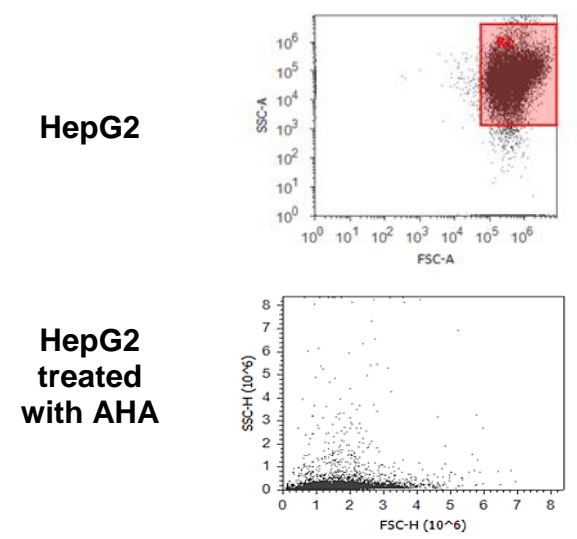

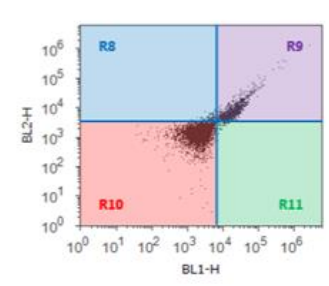

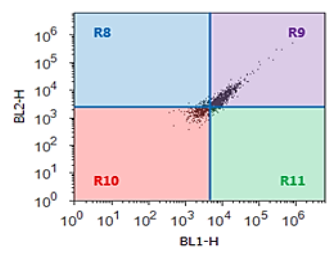

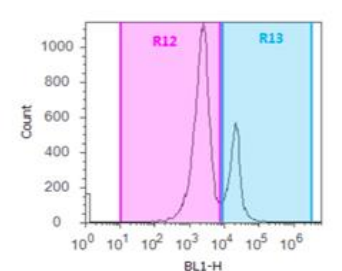

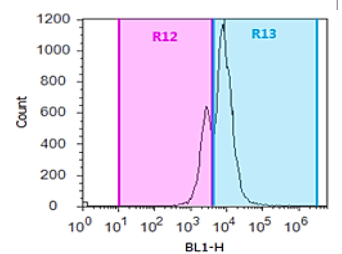

Fig. 1. Anti-proliferation effect of methanol extract of Artemisia herba alba on (hepatocellular carcinoma cell lines) during cell cycle

\subsection{Determination of the expression levels of apoptosis-regulatory genes using qRT-PCR}

Total RNA was isolated from liver cancer cell line (HepG2) using Gene JET RNA Purification Kit (Thermo Scientific, \# K0731, USA) according to the manufacturer's protocol. Then the isolated RNA was converted to cDNA using of trtro cDNA synthesis kit (Bioline, Germany). First-strand cDNA was generated to be used in the second step (for qRT-PCR). The RT reaction was amplified for synthesized cDNA using gene-specific primes of p53, $\mathrm{Bcl} 2$ and Bax which were used to detect the mRNAs levels of apoptosis-regulatory genes. The cDNA was used as a template to determine the relative expression of the apoptosis-related genes using StepOnePlus real time PCR system (Applied Biosystem, USA).

The primers were designed by Primer 5.0 software, Table (1). The housekeeping gene $\beta$-actin was used as a reference to calculate fold change in target gene expression.

Table 1. Anti-proliferation effect of methanol extract of Artemisia herba alba on (hepatocellular carcinoma cell lines) during cell cycle.

\begin{tabular}{|c|c|c|c|}
\hline \multirow{2}{*}{ Groups } & \multicolumn{3}{|c|}{$\%$ of cells in each cell cycle phase } \\
\cline { 2 - 4 } & $\begin{array}{c}\text { G0/G1 } \\
\text { phase } \\
(\text { Mean } \pm \text { SEM) }\end{array}$ & $\begin{array}{c}\text { S phase } \\
\text { (Mean } \pm \\
\text { SEM) }\end{array}$ & $\begin{array}{c}\text { G2/M phase } \\
\text { (Mean } \pm \\
\text { SEM) }\end{array}$ \\
\hline $\begin{array}{c}\text { HepG2 } \\
\text { HepG2 treated } \\
\text { with AHA }\end{array}$ & $60 \% \pm 1.40$ & $19 \% \pm 1.01$ & $21 \% \pm 1.56$ \\
\hline
\end{tabular}

\subsection{Statistical analysis}

All data were expressed as means \pm standard error (SE). The statistical significance was evaluated by one-way ANOVA using SPSS 18.0 software. Values were considered statistically significant when $\mathrm{P}<0.05$.

\section{RESULTS AND DISCUSSION}

\section{Cytotoxic activity of Artemisia herba-alba on cancer cell lines}

The anticancer activity of $A$. herba-alba methanol extract was tested on HepG2 Liver cancer cell and THLE2 liver normal cell, A549 lung cancer cell and lung normal cell lines using MTT assay. The cell viability of each cell line after exposure to different concentrations of tested extract was evaluated, whereas, the concentration of purple color increases if the cell proliferation increased. The obtained results indicated the inhibition of cell proliferation of cancer cells with increase of $A$. herbaalba crude extract dose in both cancer cell lines. On the contrary, normal cell lines exhibited extremely very low sensitivity to the high doses of tested extract. As shown in Fig. (2), inhibition concentration of $50 \%$ of cells (IC50) value for human hepatocellular carcinoma (HepG2) was 50.34 $\mu \mathrm{g} / \mathrm{ml}$, while IC50 of normal liver cells (THLE2) was $1250 \mu \mathrm{g} / \mathrm{ml}$. Meanwhile, A. herba-alba methanol extract strongly affected the cancer lung cells proliferation and viability compared with the normal lung cells, where the observed IC50 were 29.23 $\mu \mathrm{g} / \mathrm{ml}$ and $1915 \mu \mathrm{g} / \mathrm{ml}$, respectively, as shown in 
Fig. (3). These results indicated the efficient specific anti-proliferative effect of $A$.herba-alba methanol extract against the cancer cells, while it was safer toward human normal cells.

\section{Estimation of Artemisia herba alba methanol extract effect on cell cycle arrest using flow cytometry}

According to the inhibition of liver cancer (HepG2) cell viability; these results can be interpreted by the anti-proliferative effect of the Artemisia methanol extract. Therefore, cell cycle was assessed to determine if there was any cell cycle arrest by comparison between the effect on the liver cancer against the effect on the liver normal cells. As shown in Table (1), the G0/G1 phase showed a lower level from $60 \%$ to $38 \%$, S phase increased from $19 \%$ to $20 \%$ and G2/M phase recorded highly increase levels, from $21 \%$ to $42 \%$. These results suggested that the A.herba alba methanol extract has an inhibition effect on the proliferation of HepG2 cells and that by G2/M phase arrest of the cell cycle.

\section{Expression level of apoptosis related genes}

To investigate if the tested $A$.herba alba extract induced apoptosis activity in HepG2 cells or had less effect. The gene expression of apoptotic related genes such as p53, Bcl2 and Bax were evaluated using (qRT- PCR). The obtained results showed an increase in the expression level of p53 and Bax genes while the expression level of $\mathrm{Bcl} 2$ decreased. These results indicated that the $A$. herba alba crude extract destroyed HepG2 cells through apoptosis mechanism by rising the expression of p53 and Bax as apoptotic inducer genes and repression of $\mathrm{Bcl} 2$ as apoptotic inhibitor gene.

\section{General discussion}

The obtained results revealed that the A.herbaalba methanolic extract exhibited cytotoxicity effect on tested cancer cell lines according to a more intense decrease in cell viability as indicated by MTT assay, while, this extract has no effect on normal cells. So that, this result suggested that A.herba alba has anti-proliferative effect with various concentrations of methanol extract on different cancer human cell lines. These results were in agreement with the results of Kabbash (2016) who evaluated the cytotoxic effect of A.herba alba on different human cell lines such as Caco(intestinal carcinoma),HELA(cervical carcinoma), HEP2 (larynx carcinoma), HCT (colon carcinoma), A549 (lung carcinoma), HepG2 (hepatocellular carcinoma), MCF-7(breast carcinoma) and PC3(prostate carcinoma), and she reported a reduction in cell viability of all tested human cancer cell lines, therefore, A.herba alba has cytotoxic activities against cancer cell lines. In addition, the antimalarial active compound Artemisinin, which extracted from Artemisia exhibited cytotoxicity against tumor cells (Efferth, 2007).

These results are in harmony with Al-Senosy et al (2018) who found that Atriplex halimus had highly cytotoxicity against the three studied carcinoma cell lines (breast, hepatocellular and lung) using the in vitro MTT method. The results of cell cycle analysis using flow cytometry assessment showed that HePG2 cells were blocked at the G2/M phase following $24 \mathrm{~h}$ exposure to A.herba alba methanolic extract at $50.34 \mu \mathrm{g} / \mathrm{ml}$. These results were already observed in colon cancer (Caco-2) cells treated with Arthrocnemum indicum extract, and, suggested that Arthrocnemum indicum may be useful as a candidate source of antiproliferation molecules (Boulaaba et al 2013). Similar results were observed by Al-Senosy et al (2018), who found that the growth inhibited, and arrested of the cell cycle at the G2/M phase and induced apoptosis using an Atriplex halimus ethanolic extract on HePG2. revealed the presence of one or more active anticancer molecule(s) in its extract. However, Farha et al (2013) reported that analysis of cell cycle and the induction of apoptosis by accumulation of cells in G1 phase and G2/M cell cycle arrest were observed. Anti-cancer compounds arrest the cell cycle at the G1, S, or G2/M phase and then induce apoptotic cell death pathway. In addition, the function of apoptotic cell death is either removing irreparable or unrepaired damaged cells (Chen et al 2017). In the present study the mRNA expression levels of apoptoticrelated genes, i.e., p53, Bax and Bcl-2 in HepG2 cells treated with the A.herba alba crude extract were investigated. The obtained results showed that the $A$. herba alba induced apoptosis, which appeared through $\mathrm{p} 53, \mathrm{Bax}$ and $\mathrm{Bcl}-2$ genes. This finding is in agreement with several studies that demonstrated the function of p53, Bax, and Bcl-2 in causing apoptosis (Youle \& Strasser, 2008 and Al-Senosy et al 2018). 

herba alba on human cancer cell lines

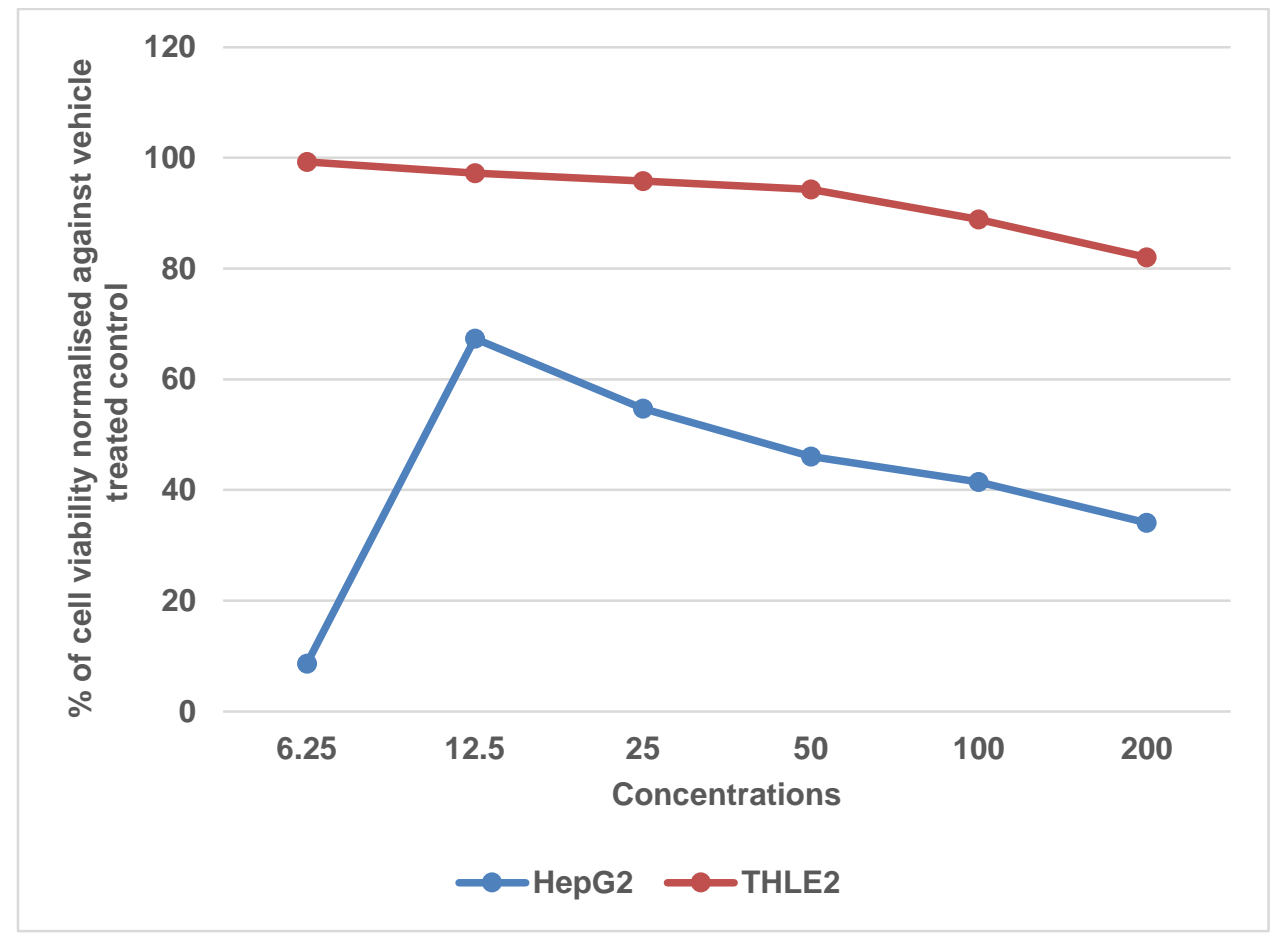

Fig. 2. Anti-proliferation effects of methanol extract of Artemisia herba alba on (nomal liver and HepG cancer) cell lines

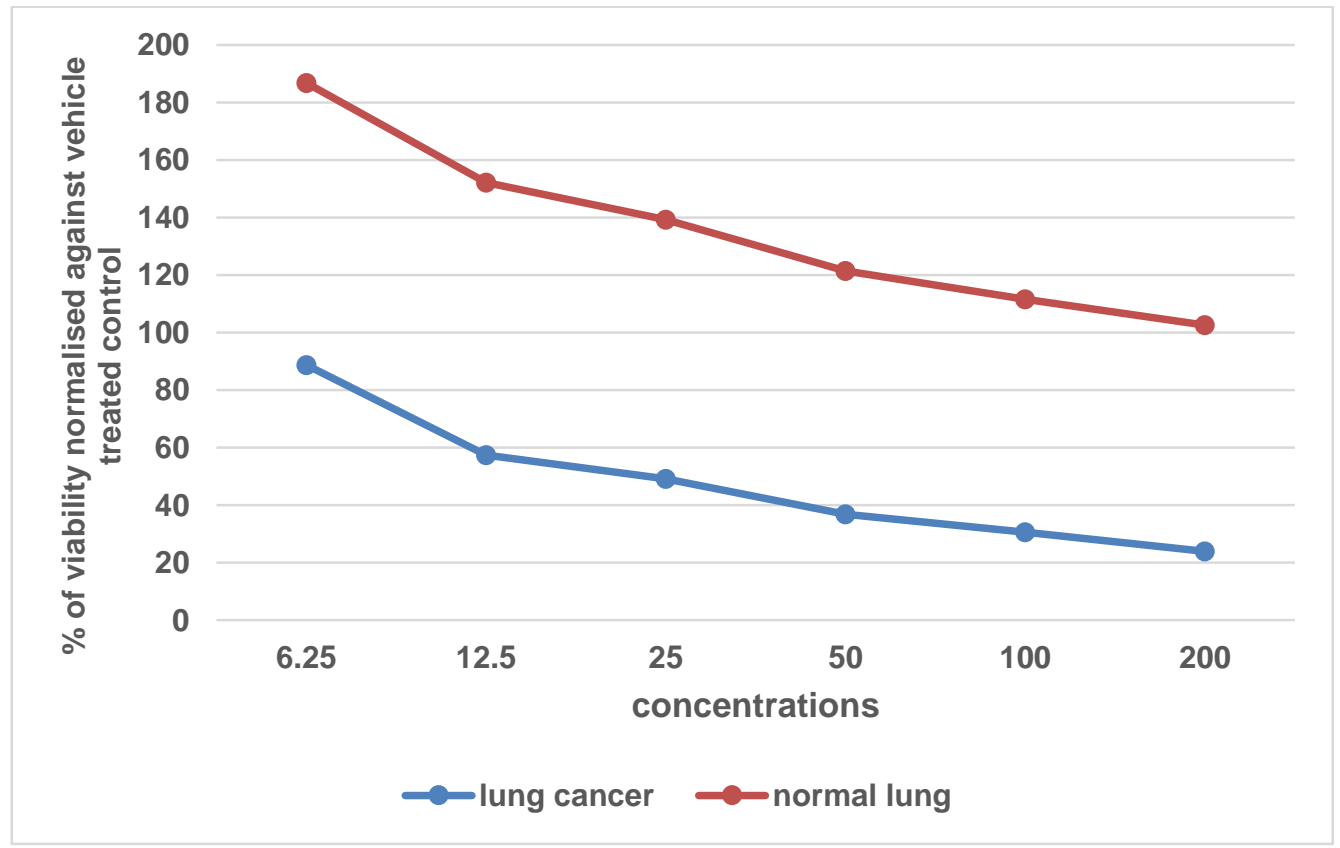

Fig. 3. antiproliferation effect of methanol extract of artemisia herba alba on ( normal lung and cancer lung) cell lines

AUJASCI, Arab Univ. J. Agric. Sci., 27(4), 2019 
Table 2. The sequence of primers that were used for each gene

\begin{tabular}{|l|l|}
\hline Primer & Sequence \\
\hline p53 & F- 5'-CCCAGGTCCAGATGAAG-3' \\
& R-5'-CAGACGGAAACCGTAGC-3' \\
\hline Bcl-2 & F-5'-GGATGCCTTTGTGGAACTGT-3' \\
& R-5'-AGCCTGCAGCTTTGTTTCAT-3' \\
\hline Bax & F-5'-TTTGCTTCAGGGTTTCATC-3' \\
& R-5'-CAGTTGAAGTTGCCGTCAGA-3'. \\
\hline
\end{tabular}

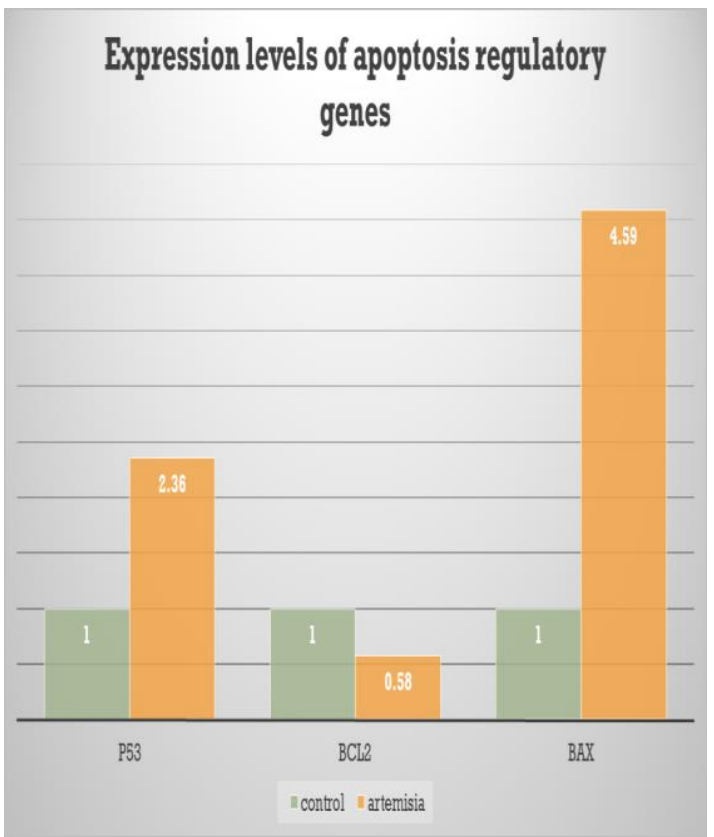

Fig. 4. Up-regulation in the expression levels of p53 and Bax genes, while the expression level of Bcl2 decreased or down-regulation

\section{CONCLUSION}

According to the findings of this study, the methanolic extract of A.herba alba has specific cytotoxic activity for human tumor cells, with no toxic effect on the normal cell. These results indicated that A.herba- alba has antiproliferative effect. Moreover, A.herba alba methanolic extract evaluated to identify the mechanisms behind the toxicity. Cell cycle blocking at the G2/M phase with apoptotic cells was proved using flow cytometry assessment and gene expression of RNA studies confirmed the activation of apoptosis pathway after cell cycle arrest. A. herba alba exhibited substantial anticancer activity against liver and lung carcinoma cell lines.

\section{REFERENCES}

Abad M.J., Bedoya L.M., Apaza L. and Bermejo, P. 2012. The Artemisia L. genus: a review of bioactive essential oils. Molecules, 17(3), 2542-2566.

Al-Senosy N.K., Abou-Eisha A. and Ahmad E.S. 2018. In vitro Antiproliferation Effect of Atriplex halimus L. Crude Extract on Human Cell Lines by Induction of Apoptosis and G2/M phase Arrest. Egyptian Academic J. of Biological Sci. C, Physiology and Molecular Biology, 10(1), 115-126.

Ashraf M., Hayat M.Q., Jabeen S., Shaheen N., Khan M.A. and Yasmin G. 2010. Artemisia L. species recognized by the local community of the northern areas of Pakistan as folk therapeutic plants. J. of Medicinal Plants Research, 4(2), 112-119.

Aziz M., Karim A, El-Ouariachi and Relaxant E.M. 2012. Effect of Essential Oil of Artemisia herba-alba Asso. On Rodent Jejunum Contractions. Scientia Pharmaceutica, 80(2), 457467.

Boulaaba M., Mkadmini K., Tsolmon S., Han J., Smaoui A., Kawada K. and Abdelly C. 2013. In vitro antiproliferative effect of Arthrocnemum indicum extracts on Caco-2 cancer cells through cell cycle control and related phenol LC-TOF-MS identification. Evidence-Based Complementary and Alternative Medicine, doi:10.1155/2013/529375.

Bray F., Ferlay J., Soerjomataram I., Rebecca L. Siegel, Lindsey A. Torre and Jemal A. 2018. Global Cancer statistics 2018: GLOBOCAN Estimates of incidence and Mortality Worldwide for 36 Cancers in 185 Countries. Cancer J. Clin. 68, 394-424.

Chen Y., Qin Y., Li L., Chen J., Zhang X. and Xie Y. 2017. Morphine can inhibit the growth of breast cancer MCF-7 cells by arresting the cell cycle and inducing apoptosis. Biological and Pharmaceutical Bulletin, 40(10), 1686-1692.

Dhanya S.R., Geetha B.S., Latha P.G., Farha K., Nair M.S. and Remani P. 2013. Apoptosis mediated cytotoxicity induced by isodeoxyelephantopin on nasopharyngeal carcinoma cells. Asian J. of Pharamceutical and Clinical Res., 6(2), 51-56. 
Efferth T., Giaisi M., Merling A., Krammer P.H., and Li-Weber M. 2007. Artesunate induces ROS-mediated apoptosis in doxorubicinresistant T leukemia cells. Plos one. 2(8), e693.

Florento L., Matias R., Tuaño E., Santiago K., Dela Cruz F. and Tuazon A. 2012. Comparison of Cytotoxic Activity of Anticancer Drugs against Various Human Tumor Cell Lines Using In Vitro Cell-Based Approach. Int. J. of Biomedical Sci. IJBS, 8(1), 76-80.

Gazdar A.F., Girard L., Lockwood W.W., Lam W.L. and Minna J.D. 2010. Lung cancer cell lines as tools for biomedical discovery and research. J. of the National Cancer Institute, 102(17), 1310-1321.

Gersten O. and Wilmoth J.R. 2002. The cancer transition in Japan since 1951. Demographic Research, 7, 271-306.

Gordanian B., Behbahani M., Carapetian J. and Fazilati M. 2014. In vitro evaluation of cytotoxic activity of flower, leaf, stem and root extracts of five Artemisia species. Research in Pharmaceutical Sci., 9(2), 91-96.

Jaleel G.A.R.A., Abdallah H.M.I. and Gomaa N.E.S. 2016. Pharmacological effects of ethanol extract of Egyptian Artemisia herba-alba in rats and mice. Asian Pacific J. of Tropical Biomedicine, 6(1), 44-49.

Kabbash A.M. 2016. Macroscopic and microscopic characterization of Artiplex nalimus L. growing activites. World J. Pharm Pharm Sci., 5(6), 84-100.

Kao J., Salari K., Bocanegra M., Choi Y.L., Girard L., Gandhi J. and Minna J.D. 2009. Molecular profiling of breast cancer cell lines defines relevant tumor models and provides a resource for cancer gene discovery. PloS one, 4(7), e6146.

Khalafalla M.M., Abdellatef E., Dafalla H.M., Nassrallah A.A., Aboul-Enein K.M., Lightfoot D.A. and El-Shemy H.A. 2010. Active principle from Moringa oleifera Lam leaves effective against two leukemias and a hepatocarcinoma. African J. of Biotechnology, 9(49), 84678471.

Louzada S., Adega F. and Chaves R. 2012. Defining the sister rat mammary tumor cell lines $\mathrm{HH}-16 \mathrm{cl}$. 2/1 and $\mathrm{HH}-16$. cl. 4 as an in vitro cell model for Erbb2. PloS one, 7(1), e29923.
Majdouli K., Soro N.K. and El-Azzouzi H. 2015. Chemical composition of antibacterial activity of Artemisia herba-alba Hugueii essential oil from south of morocco. Int. J. Curr Res., 7(14), 397404.

Mansi K., Amneh M. and Nasr H. 2007. The hypolipidemic effects of Artemisia sieberi (A. herba-alba) in alloxan induced diabetic rats. Int. J. of Pharmacology, 3(6), 487-491.

Mohamed A.E.H.H., El-Sayed M., Hegazy M.E., Helaly, S.E., Esmail A.M. and Mohamed N.S. 2010. Chemical constituents and biological activities of Artemisia herba-alba. Records of Natural Products, 4(1), 1-25.

Nakatsu N., Yoshida Y., Yamazaki K., Nakamura T., Dan S., Fukui Y. and Yamori T. 2005. Chemosensitivity profile of cancer cell lines and identification of genes determining chemosensitivity by an integrated bioinformatical approach using cDNA arrays. Molecular cancer therapeutics, 4(3), 399-412.

Pozarowski P. and Darzynkiewicz Z. 2004 Analysis of Cell Cycle by Flow Cytometry. In: Schönthal A.H. (eds) Checkpoint Controls and Cancer. Methods in Molecular Biology, 281, 301-311.

Shoemaker R.H. 2006. The NCI60 human tumour cell line anticancer drug screen. Nature $\boldsymbol{R e}$ views Cancer, 6(10), 813-823.

Tilaoui M., Mouse H.A., Jaafari A., Aboufatima R., Chait A. and Zyad A. 2011. Chemical composition and antiproliferative activity of essential oil from aerial parts of a medicinal herb Artemisia herba-alba. Revista Brasileira de Farmacognosia, 21(4), 781-785.

Van Staveren W.C.G., Solís D.W., Hebrant, A., Detours V., Dumont J.E. and Maenhaut C. 2009. Human cancer cell lines: Experimental models for cancer cells in situ? For cancer stem cells? Biochimica et Biophysica Acta (BBA)-Reviews on Cancer, 1795(2), 92-103.

Vargo Gogola T. and Rosen J.M. 2007. Modelling breast cancer: one size does not fit all. Nature Reviews Cancer, 7(9), 659-672.

Youle R.J. and Strasser A. 2008. The BCL-2 protein family: opposing activities that mediate cell death. Nature Reviews Molecular Cell Biology, 9(1), 47-59. 


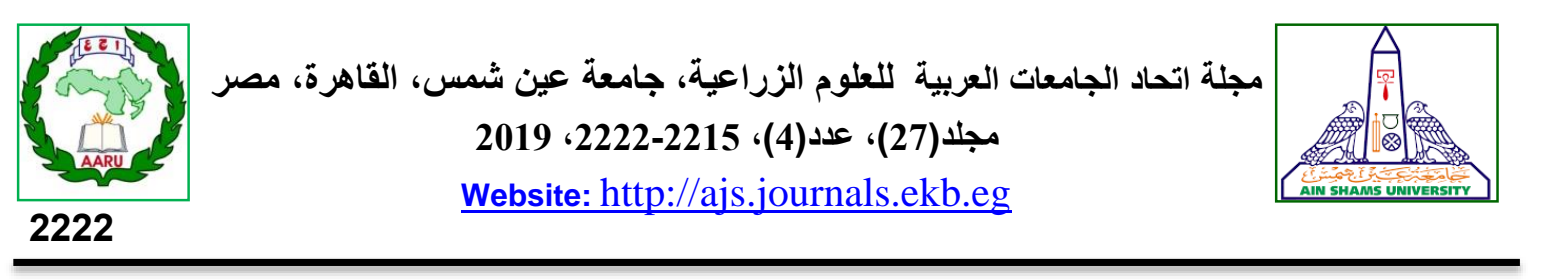

تقييم النشاط المضاد للسرطان للمستخلص الميثانولى لنبات الثيح على خطوط خلايا سرطان الكبد والرئة في الإنسان

[176]

$$
\text { قدم الوراثة - كلية الزراعة - جمد" - نعمة قطب السنوسى - نجلاء محمد عبيد - خالد بن الوليد فهمى - } 68 \text { - حدائق شبرا } 11241 \text { - القاهرة - مصر }
$$

*Corresponding author: hadeer@agr.asu.edu.eg

Received 6 November, 2019 Accepted 24 November, 2019

وتبين من خلال تقنية التدفق الخلوى أن ظاهرة

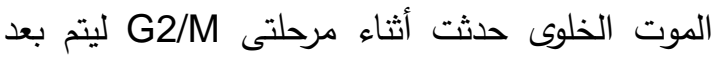

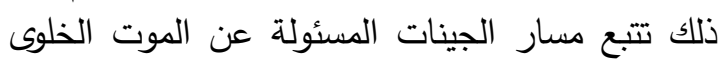

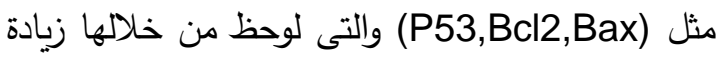

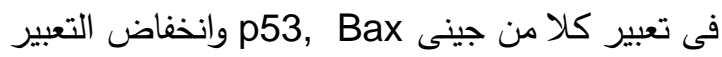

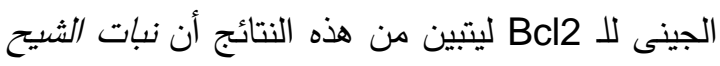

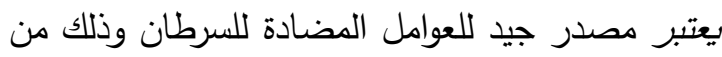

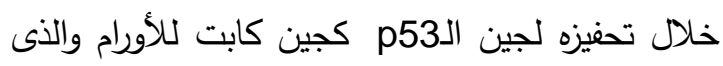

بدوره يستحث جين الـBax وهو الجين المشفر والمسئول

عن تثبيط Bcl2 المسئول عن منع عملية الموت المين

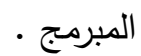

الكلمات الدالة: نباتات طبية، تأثير المضاد للسرطان، المبان،

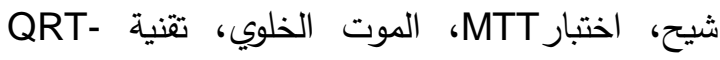

PCR

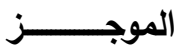

فى إطار البحث عن منتجات طبية طبيعية مضادة

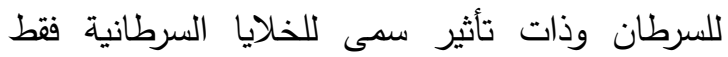
وليس لها تأثير على الخلايا الطبيعية أو تكون ذات الثير

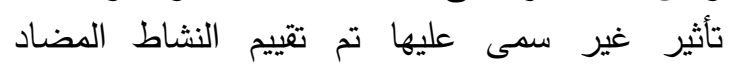

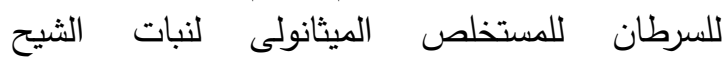
Artemisia herba alba

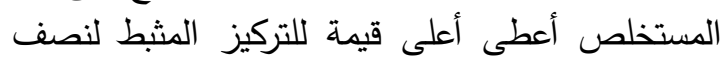
عدد الخلايا (IC50) على خطوط الخلايا السرطانية للرئة والكبد بقيمة 29.23 ميكروجرام/مل، 50.34 ميكروجرام/مل علي التوالي.

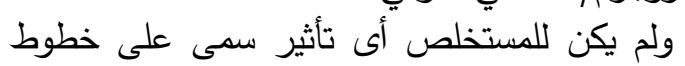

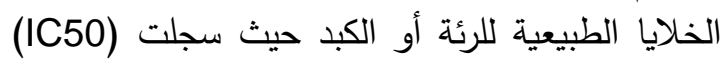

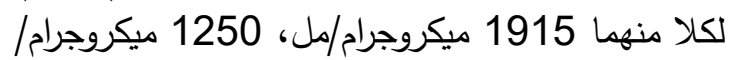

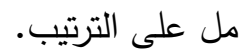

